\title{
PERBANDINGAN ABNORMAL RETURN DAN VOLUME PERDAGANGAN SAHAM SEBELUM DAN SESUDAH KEBIJAKAN TAX AMNESTY PERIODE I (Study Kasus Pada Bank Persepsi Penerima Dana Uang Tebusan Tax Amnesty Yang Terdaftar di BEI)
}

\author{
Wahyuni Retno Wulandari ${ }^{(1}$, Agus Sudrajat ${ }^{(2}$ \\ Program Studi Akuntansi, Universitas PGRI Madiun \\ zoebieirioen@yahoo.com \\ agus.sudrajat84@gmail.com
}

\begin{abstract}
Mentioned one of the announcements that may affect the price of the securities are governmentrelated announcements, tax amnesty policy is one of the government's policy so it is considered to have an influence on the world of investment in the capital market, therefore this research want to see whether the existence of tax amnesty policy can give abnormal return (AR) and increase volume of stock trading (TVA) on stocks of banks receiving money ransom amnesty tax period I.

This research uses event study method. The research data uses secondary data consisting of monthly stock closing price and monthly stock trading volume with 3 months observation period before and 3 months after tax amnesty period I. The market adjusted model is used to calculate the expected return. The hypothesis was tested using paired samples t-test. The samples used are 20 beneficiary taxpayer banks registered on IDX with complete data and normally distributed with one-kolmogorov smirnov test.

The results of this study indicate that tax amnesty policy of period I has an effect on abnormal return and no effect to stock trading volume before and after tax amnesty period I.
\end{abstract}

Keywords: Tax Amnesty, Abnormal Return, Stock Trading Volume

\begin{abstract}
ABSTRAK
Disebutkan salah satu pengumuman yang dapat mempengaruhi harga dari sekuritas adalah pengumuman-pengumuman yang berhubungan dengan pemerintah (Government-Related Announcement), kebijakan tax amnesty merupakan salah satu dari kebijakan pemerintah sehingga dianggap memberikan pengaruh terhadap dunia investasi di pasar modal, oleh karena itu penelitian ini ingin melihat apakah dengan adanya kebijakan tax amnestydapat memberikan abnormal return (AR) dan peningkatan volume perdagangan saham (TVA) pada saham-saham bank penerima dana uang tebusan tax amnestyperiode I. Penelitian ini menggunakan metode event study. Data penelitian menggunakan data sekunder yang terdiri dari harga penutupan saham bulanan dan volume perdagangan saham bulanan dengan periode pengamatan 3 bulan sebelum dan 3 bulan sesudah tax amnesty periode I. Model disesuaikanpasar digunakan untuk menghitung return ekspektasian. Hipotesis diuji dengan menggunakan paired samples t-test. Sampel yang digunakan adalah 20 bank penerima dana uang tebusan tax amnestyyang terdaftar di BEI dengan data lengkap dan terdistribusi normal dengan uji one-kolmogorov smirnov. Hasil penelitian ini menunjukkan bahwa kebijakan tax amnesty periode Iberpengaruh terhadap abnormal return dan tidak berpengaruhuntuk volume perdagangan saham sebelum dan sesudah tax amnesty periode I.
\end{abstract}

Kata kunci : Tax Amnesty, Abnormal Return, Volume Perdagangan Saham

\section{PENDAHULUAN}

Sebagai salah satu instrumen bisnis ekonomi, pasar modal tidak lepas dari berbagai pengaruh lingkungan yang mencakup faktor ekonomi baik yang berasal dari internal maupun eksternalperusahaan serta faktor non ekonomi seperti faktor sosial, politik dan faktor lainnya yang mengganggu stabilitas nasional suatu negara.

Yang menjadi perhatian para investor dari peristiwa terkini adalah adanya kebijakan pemerintah tentang 
diberlakukannya Undang-undang tax amnesty di Indonesia.

Disinyalir masih banyak harta warga Indonesia yang belum dilaporkan kedalam perpajakan seperti yang dikemukakan oleh Tito Sulistyo direktur utama BEI dalam wawancaranya dengan majalah pajak bahwa jumlah transaksi diIndonesia $65 \%$ atas nama asing dan $35 \%$ atas nama domestik tapi sebagian dari transaksi ini sebenarnya orang Indonesia yang menggunakan atas nama asing. Hal inilah yang mendasari pemerintah untuk mengadakan tax amnesty agar transparansi kepemilikan harta tercapai. Sehingga harta-harta yang belum dilaporkan dapat segera dilaporkan dan dataperpajakan dapat sesuai dengan kenyataan tanpa adanya harta-harta yang disembunyikan oleh para pemilik usaha maupun bukan ("PAJAK," 2017).

$\begin{array}{lrrr} & \text { Presiden } & \text { Republik Indonesia } \\ \text { pada tanggal } & 1 \text { Juli } 2016 \\ \text { mengesahkan } & \text { Undang-Undang }\end{array}$ Republik Indonesia No.11 Tahun 2016 tentang Pengampunan Pajak berlaku hingga 31 Maret 2017 dan terbagi ke dalam 3 periode yaitu Periode I: Dari tanggal diundangkan s.d 30 September 2016, Periode II: Dari tanggal 1 Oktober 2016 s.d 31 Desember 2016, Periode III: Dari tanggal 1 Januari 2017 s.d 31 Maret 2017

(www.pajak.go.id/content/amnestipajak).

Menurut UU tax amnesty No 11 tahun 2016 Pengampunan Pajak (tax amnesty) adalah penghapusan pajak yang seharusnya terutang, tidak dikenai sanksi administrasi perpajakan dan sanksi pidana di bidang perpajakan, dengan cara mengungkap Harta dan membayar
Uang Tebusan sebagaimana diatur dalam Undang-Undang ini (UU-112016-Pengampunan-Pajak-BatangTubuh).

Direktur Utama BEI Tito Sulistio dalam Denpasar, Kompas.com satu Oktober 2016 mengatakan, biasanya transaksi harian di bursa saham sekitar Rp 5,5 triliun dan sejak adanya program amnesty pajak melonjak jadi $\mathrm{Rp} 8$ triliun.

Seperti dilansir dari $\mathrm{CNN}$ Indonesia aliran dana repatriasi dari pelaksanaan pengampunan pajak yang disinyalir mengendap disektor perbankan, pelan-pelan mulai mengalir ke pasar modal. Hal ini dibuktikan dengan IHSG yang ditutup menguat 29,66 poin $(0,53 \%)$ ke levell 5,563 setelah bergerak diantara 5.532-5.576 dan sebanyak 195 saham naik, 119 saham turun dan 106 saham tidak bergerak serta investor membukukan transaksi sebesar Rp 8,06 triliun dengan volume 11,66 miliar lembar saham pada hari kamis 23 maret 2017.

(https://www.cnnindonesia.com/ekon omi/20170323163746-92-

202302/ihsg-menanjak-tembus-rekordi-level-5563/)

Reaksi Investor terhadap suatu informasi dapat diukur dengan melihat abnormal return. Apabila suatu peristiwa tidak menimbulkan suatu abnormal return, berarti para investor tidak bereaksi atau tidak ada reaksi pasar, karena reaksi pasar oleh para investor terhadap suatu informasi yang baru ditunjukan dengan adanya abnormal return Hartono (dalam wulandari dkk, 2017). Dan begitu juga sebaliknya apabila abnormal return signifikan maka para investor bereaksi pada suatu peristiwa tersebut. 



tertentu (Suardi dkk, 2015). 


\section{METODE PENELITIAN}

Desain penelitian yang digunakan adalah event study atau studi peristiwa. Studi peristiwa (event study) merupakan studi yang mempelajari reaksi pasar terhadap suatu peristiwa (event) yang informasinya dipublikasikan sebagai suatu pengumuman (Jogiyanto, 2013:585).

$$
\text { Jogiyanto }
$$

menyatakan bahwa studi peristiwa (event study) dapat digunakan untuk menguji kandungan informasi (information content) dari suatu pengumuman dan dapat juga digunakan untuk menguji efisiensi pasar bentuk setengah kuat. Pengujian kandungan informasi dan pengujian efesiensi pasar bentuk setengah kuat merupakan dua pengujian yang berbeda. Periode yang digunakan dalam penelitian ini adalah 3 bulan sebelum tax amnesty periode I dan 3 bulan sesudah tax amnesty periode I.

$$
\text { Untuk variabel yang }
$$

digunakan adalah kebijakan tax amnesty periode I, abnormal return dan volume perdagangan saham. Subjek penelitian adalah bank yang ditunjuk pemerintah sebagai penerima dana uang tebusan tax amnesty yang terdaftar di BEI dengan data yang lengkap periode April 2016-Juni 2016 dan Oktober 2016-Desember 2017.

Populasi dalam penelitian ini adalah bank yang ditunjuk pemerintahsebagai penerima dana uang tebusan tax amnesty tahun 2016. Alasan penggunaan bank penerima dana uang tebusan adalah karena penelitian ini berfokus pada bank yang ditunjuk oleh pemerintah sebagai penerima uang tebusan tax amnesty yaitu sebanyak 77 bank persepsi penerima dana uang tebusan tax amnesty. Sampel dalam penelitian ini adalah bank penerima uang dana tebusan tax amnesty yang telah ditunjuk oleh pemerintah yang terdaftar di BEI dengan data yang lengkap yaitu sebanyak 20 bank. Teknik pengambilan sampel dalam penelitian ini dipilih sesuai dengan kriteria sebagai berikut :

a.Bank yang terdaftar di Bursa Efek Indonesia (BEI).

b.Bank yang ditunjuk pemerintah dan menteri keuangan sebagai penerima dana uang tebusan tax amnesty yaitu 77 bank.
c.Bank yang ditunjuk pemerintah sebagai penerima dana uang tebusan tax amnesty dengan data yang lengkap yaitu :

Sehingga teknik pengambilan sampel yang digunakan adalah sampling purposive. Sampling purposive adalah teknik penentuan sampel dengan pertimbangan tertentu (Sugiyono, 2015:85).

Jenis data yang digunakan adalah data kuantitaif sedangkan sumber pengumpulan data yang digunakan dalam penelitian ini adalah sumber data sekunder. Untuk teknik pengumpulan data menggunakan teknik dokumentasi. Dan teknik analisis data yang digunakan dalam penelitian ini adalah uji beda atau paired sample $t$ test. Metode ini digunakan untuk menguji apakah ada perbedaan antara abnormal return dan volume perdagangan saham sebelum dan sesudah tax amnesty periode I. Dalam paired sample t test mensyaratkan harus melakukan uji asumsi klasik terlebih dahulu yaitu berupa uji normalitas data.

\section{HASIL DAN PEMBAHASAN HASIL Hasil \\ Uji Paired sample $t$ test digunakan untuk menguji apakah ada perbedaan}


antara abnormal return dan volume perdagangan saham sebelum dan sesudah tax amnesty periode I. Sebelum melakukan uji beda terlebih dahulu melakukan uji normalitas data abnormal return dan volume perdagangan saham sebelum dan sesudah tax amnesty periode I menggunakan uji One-Sample Kolmogorov-Smirnov Test, seperti nampak pada tabel dibawah ini :

\section{Tabel 1}

\section{Uji Normalitas Data}

One-Sample Kolmogorov-Smirnov Test

\begin{tabular}{|c|c|c|c|c|c|}
\hline & & $\begin{array}{l}\text { Abnormal__ } \\
\text { Return_Sebelum } \\
\text { TA_Periode_I }\end{array}$ & $\begin{array}{l}\text { Abnormal_ } \\
\text { Return_Setelah_- } \\
\text { TA_Periode_I }\end{array}$ & $\begin{array}{c}\text { Volume_- } \\
\text { Perdagangan_ } \\
\text { Saham_- } \\
\text { Sebelum_- } \\
\text { TA_Periode_I }\end{array}$ & $\begin{array}{c}\text { Volume_- } \\
\text { Perdagangan_ } \\
\text { Saham_- } \\
\text { Setelah-- } \\
\text { TA_Periode_I }\end{array}$ \\
\hline \multicolumn{2}{|l|}{$\mathrm{N}$} & 20 & 20 & 20 & 20 \\
\hline \multirow[t]{2}{*}{ Normal Parameters ${ }^{\mathrm{a}, \mathrm{b}}$} & Mean & 4422.2358 & 5077.1161 & .0043 & .0074 \\
\hline & Std. Deviation & 9056.62713 & 10049.87108 & .00469 & .00988 \\
\hline \multirow{3}{*}{$\begin{array}{l}\text { Most Extreme } \\
\text { Differences }\end{array}$} & Absolute & .300 & .278 & .212 & .226 \\
\hline & Positive & .300 & .278 & .212 & .203 \\
\hline & Negative & -.260 & -.251 & -.182 & -.226 \\
\hline \multicolumn{2}{|l|}{ Kolmogorov-Smirnov Z } & 1.340 & 1.245 & .948 & 1.011 \\
\hline \multicolumn{2}{|l|}{ Asymp. Sig. (2-tailed) } & .055 & .090 & .330 & .258 \\
\hline
\end{tabular}

Dari tabel di atas terlihat bahwa hasil uji normalitas abnormal return dan volume perdagangan saham sebelum tax amnesty periode I dengan taraf signifikansi sebesar 5\% menunjukan bahwa hasil signifikansi masing-masing $\quad 0.55$ dan 0.330 sehingga data dinyatakan berdistribusi normal karena hasil signifikansi lebih besar dari taraf siginifikansi 5\%. Sedangkan uji normalitas abnormal return dan volume perdagangan saham setelah tax amnesty periode I menunjukan hasil signifikansi masing-masing 0.90 dan 0.258 sehingga data dinyatakan berdistribusi normal karena hasil signifikansi lebih besar dari taraf siginifikansi $5 \%$.

Pengujian Hipotesis menggunakan paired sample t test dengan bantuan program Statistical Package for Social Science (SPSS) 17,0 For Windows, yang memperoleh hasil perhitungan uji statistik abnormal returnsebelum dan sesudah tax amnesty periode I yang dapat dilihat pada tabel dibawah ini : 
Tabel 2

Paired Samples Test

\begin{tabular}{|c|c|c|c|c|c|c|c|c|c|}
\hline \multicolumn{10}{|c|}{ Paired Differences } \\
\hline & & \multirow[t]{2}{*}{ Mean } & \multirow[t]{2}{*}{$\begin{array}{c}\text { Std. } \\
\text { Deviation }\end{array}$} & \multirow[t]{2}{*}{$\begin{array}{l}\text { Std. Error } \\
\text { Mean }\end{array}$} & \multicolumn{2}{|c|}{$\begin{array}{l}95 \% \text { Confidence } \\
\text { Interval of the } \\
\text { Difference }\end{array}$} & \multirow[t]{2}{*}{$\mathrm{t}$} & \multirow[t]{2}{*}{$\mathrm{df}$} & \multirow[t]{2}{*}{$\begin{array}{l}\text { Sig. (2- } \\
\text { tailed) }\end{array}$} \\
\hline & & & & & Lower & Upper & & & \\
\hline $\begin{array}{l}\text { Pair } \\
1\end{array}$ & $\begin{array}{l}\text { AR_Sebelum_T } \\
\text { A_Periode_I- } \\
\text { AR_Sesudah_T } \\
\text { A_Periode_I }\end{array}$ & -654.88025 & 1293.41504 & 289.21639 & -1260.21712 & -49.54338 & -2.264 & 19 & .035 \\
\hline
\end{tabular}

Dari table 1.2 diatas diperoleh hasil $t_{\text {hitung }}$ sebesar $-2,264$ dan $t_{\text {tabel }}$ sebesar 2,093 (yang diperoleh dari $\mathrm{t}$ table) dengan nilai signifikan $0,035<0,05$ oleh karena $t_{\text {hitung }}>t_{\text {tabel }}$ dan sig 2 tailed $<0,05$ maka $\mathrm{H}_{1}$ diterima. Jadi dapat disimpulkan bahwa terdapat perbedaan yang signifikan abnormal returnbank penerima dana uang tebusan tax amnestysebelum dan setelahtax amnesty periode I.

Pengujian yang sama juga digunakan untuk mengetahui perbedaan aktivitas volume perdagangan saham sebelum dan sesudah peristiwa tax amnesty periode I. Berdasarkan uji statistik yang telah dilakukan, maka diperoleh hasil perhitungan uji statistik seperti dibawah ini :

Tabel 3

Paired Samples Test

\begin{tabular}{|c|c|c|c|c|c|c|c|c|c|}
\hline \multicolumn{10}{|c|}{ Paired Differences } \\
\hline & & \multirow[t]{2}{*}{ Mean } & \multirow[t]{2}{*}{$\begin{array}{c}\text { Std. } \\
\text { Deviation }\end{array}$} & \multirow[t]{2}{*}{$\begin{array}{l}\text { Std. Error } \\
\text { Mean }\end{array}$} & \multicolumn{2}{|c|}{$\begin{array}{l}95 \% \text { Confidence } \\
\text { Interval of the } \\
\text { Difference }\end{array}$} & \multirow[t]{2}{*}{$\mathrm{t}$} & \multirow[t]{2}{*}{$\mathrm{df}$} & \multirow[t]{2}{*}{$\underset{\text { (2-tailed) }}{\text { Sig. }}$} \\
\hline & & & & & Lower & Upper & & & \\
\hline $\begin{array}{l}\text { Pair } \\
1\end{array}$ & $\begin{array}{l}\text { TVA_Sebelum_TA } \\
\text { Periode_I - } \\
\text { TVA_Setelah_TA_T } \\
\text { Periode_I }\end{array}$ & -.00318 & .00920 & .00206 & -.00749 & .00112 & -1.547 & 19 & .138 \\
\hline
\end{tabular}

Dari table diatas diperoleh hasil $t_{\text {hitung }}$ sebesar -1.547 dan $t_{\text {tabel }}$ sebesar -2,093 (yang diperoleh dari t table) dengan nilai signifikan $0.138>0,05$ oleh karena $t_{\text {hitung }}<t_{\text {tabel }} d a n$ sig 2 tailed $>$ 0,05 maka $\mathrm{H}_{2}$ ditolak. Jadi dapat disimpulkan bahwa tidak terdapat perbedaan yang tidak signifikan volume perdagangan saham bank penerima dana uang tebusan tax amnestysebelum dan setelahtax amnesty periode.

PEMBAHASAN

Perbedaan Adanya Tax AmnestyPeriode I Terhadap Abnormal Return

Berdasarkan dari hasil pengujian penelitian ini menunjukkan bahwa terdapat perbedaan abnormal return bank penerima dana uang tebusan $\operatorname{tax}$ 
amnesty sebelum dan setelah tax amnesty periode I. Hal ini ditunjukkan dari hasil statistik abnormal return pada tabel 4.7 yang menunjukkan bahwa nilai $t_{\text {hitung }}$ sebesar -2,264 dan $t_{\text {tabel }}$ sebesar $-2,093$ dengan nilai signifikan $0,035<0,05$.

Seperti yang dikemukakan oleh direktur Utama BEI Tito Sulistio dalam Denpasar, Kompas.com satu Oktober 2016 mengatakan, biasanya, transaksi harian di bursa saham sekitar Rp 5,5 triliun dan sejak adanya program amnesty pajak melonjak jadi Rp 8 triliun. Berita tersebut mendukung hasil penelitian ini bahwa terdapat perbedaan abnormal return bank penerima dana uang tebusan tax amnesty sebelum dan setelah tax amnesty periode I.

Menurut Hartono (dalam Kemala dan ulupui, 2015) suatu informasi berguna bagi investor jika informasi tersebut mengundang respon investor untuk menanamkan modal. Ada tidaknya reaksi dilihat dari rata-rata abnormal return. Dalam penelitian Suardi dkk (2015) menjelaskan reaksi pasar ditunjukan dengan adanya perubahan harga dari sekuritas bersangkutan. Reaksi ini dapat diukur dengan menggunakan abnormal return dan volume perdagangan saham. Sehingga dapat diartikan adanya tax amnesty memberikan abnormal return hal ini menunjukan bahwa pasar modal atau investor merespon positif kebijakan tax amnesty tahun 2016. Disebutkan juga salah satu macam-macam dari pengumuman yang dapat mempengaruhi harga dari sekuritas adalah adanya "Pengumumanpengumuman yang berhubungan dengan pemerintah (GovernmentRelated Announcement), a) Dampak dari peraturan baru, b) Investigasiinvestigasi terhadap kegiatan perusahaan, c) Keputusan-keputusan regulator, d) lainnya (Jogiyanto, 2013:551). Hal ini semakin mendukung bahwa adanya kebijakan tax amnesty yang merupakan salah satu pengumuman-pengumuman dari pemerintah mempengaruhi harga dari sekuritas atau saham karena berdasarkan penjelasan-penjelasan diatas dan hasil dari penelitian ini menunjukan adanya abnormal return setelah tax amnesty periode I. Hal ini ditunjukkan dari nilai $t_{\text {hitung }}>t_{\text {tabel }}$ sebesar $-2,264>-2,093$ dengan signifikansi yang berada di bawah 0,05 . Dengan kata lain $\mathrm{H}_{1}$ diterima. Dengan demikian para investor merespon adanya tax amnesty periode I tahun 2016 tersebut sebagai sesuatu yang memiliki kandungan informasi. Hasil penelitian ini didukung oleh penelitian yang dilakukan oleh Wulandari dkk (2017), yang menguji apakah terdapat perbedaan abnormal return dan aktivitas volume perdagangan saham sebelum dan sesudah peristiwa berlakunya Undang-undang tax amnesty. Penelitian tersebut memperoleh hasil bahwa terdapat perbedaan yang signifikan antara abnormal return sebelum dan sesudah peristiwa berlakunya Undang-undang tax amnesty.

Sedangkan penelitian yang dilakukan oleh Asmorojati, dkk (2016) menemukan hasil bahwa meskipun pengumuman kebijakan tax amnesty pada tanggal 1 Juli 2016 merupakan berita baik (good news), namun pengumuman tersebut tidak memiliki kandungan informasi yang berarti bagi investor, sehingga menyebabkan pasar modal tidak bereaksi. Begitu juga dengan penelitian yang dilakukan oleh Rahayu (2016) dengan judul Analisis Reaksi Pasar Modal Terhadap Kebijakan Tax Amnesty memperoleh hasil kebijakan amnesty 
pajak tidak memberikan abnormal return pada saham-saham syariah yang terdaftar di JII.

Dengan demikian hipotesis yang menyatakan terdapat perbedaan abnormal return sebelum dan setelah tax amnesty periode I dapat diterima.

\section{Perbedaan adanya tax amnesty terhadap Volume Perdagangan Saham}

Berdasarkan dari hasil pengujian penelitian ini menunjukkan bahwa tidak terdapat perbedaan volume perdagangan saham bank penerima dana uang tebusan tax amnesty sebelum dan setelah tax amnesty periode I. Hal ini ditunjukkan dari hasil statistik volume perdagangan saham sebesar -1.547 dan $t_{\text {tabel }}$ sebesar -2,093 dengan nilai signifikan $0.138>0,05$. Hal ini menunjukan bahwa tidak terdapat perbedaan volume perdagangan sahambank penerima dana uang tebusan tax amnestysebelum dan setelahtax amnesty periode I.

Menurut Jogiyanto (dalam Suardi dkk, 2015) para pelaku pasar modal akan mengevaluasi setiap pengumuman yang diterbitkan oleh emiten, sehingga hal tersebut akan menyebabkan beberapa perubahan pada transaksi perdagangan saham, misalnya adanya perubahan pada volume perdagangan saham, perubahan pada harga saham, bid/ask spread dan promosi kepemilikan. Dengan hasil penelitian yang dipaparkan penulis diatas dapat diartikan bahwa tidak ada respon para pelaku pasar modal terhadap tax amnesty, hal ini dapat dilihat pada hasil penelitian yang menunjukan tidak adanya perbedaan dan signifikan antara volume perdagangan saham sebelum dan setelah tax amnesty periode I yang ditunjukkan dari nilai $t_{\text {hitung }}>t_{\text {tabel }}$ sebesar $-1.547>$ 2,093 dengan signifikansi yang berada di atas 0,05 . Atau dengan kata lain $\mathrm{H}_{2}$ ditolak. Dengan demikian adanya tax amnesty periode I tidak menarik minat investor dalam membeli saham pada bank penerima dana uang tebusan tax amnesty tahun2016.

Hasil penelitian ini didukung oleh penelitian yang dilakukan oleh Asmorojati, dkk (2016) menemukan hasil bahwa meskipun pengumuman kebijakan tax amnesty pada tanggal 1 Juli 2016 merupakan berita baik (good news), namun pengumuman tersebut tidak memiliki kandungan informasi yang berarti bagi investor, sehingga menyebabkan pasar modal tidak bereaksi. Begitu juga dengan penelitian yang dilakukan oleh Rahayu (2016) dengan judul Analisis Reaksi Pasar Modal Terhadap Kebijakan Tax Amnesty memperoleh hasil kebijakan amnesty pajak tidak memberikan perbedaan volume perdagangan saham pada sahamsaham syariah yang terdaftar di JII.

Sedangkan penelitian yang dilakukan oleh Wulandari dkk (2017), yang menguji apakah terdapat perbedaan abnormal return dan aktivitas volume perdagangan saham sebelum dan sesudah peristiwa berlakunya Undang-undang tax amnesty. Penelitian tersebut memperoleh hasil bahwa terdapat perbedaan yang signifikan antara volume perdagangan saham sebelum dan sesudah peristiwa berlakunya Undang-undang tax amnesty. Dengan demikian hipotesis yang menyatakan terdapat perbedaan volume perdagangan saham sebelum dan setelah tax amnesty periode I tidak dapat diterima. 


\section{SIMPULAN DAN SARAN \\ Simpulan}

Dari hasil penelitian yang dilakukan

berdasarkan permasalahan yang

terdapat dalam rumusan masalah

dapat disimpulkan sebagai berikut:

1. Berdasarkan hasil uji statistik terhadap abnormal return pada bank penerima dana uang tax amnesty sebelum dan setelah tax amnesty periode I, ditemukan bahwa terdapat perbedaan dan signifikan antara abnormal return sebelum dan setelah tax amnesty periode I.

2. Berdasarkan hasil uji statistik terhadap volume perdagangan saham pada bank penerima dana uang tax amnesty sebelum dan setelah tax amnesty periode I, ditemukan bahwa tidak terdapat perbedaan dan tidak signifikan antara volume perdagangan saham sebelum dan setelah tax amnesty periode I.

\section{Saran}

Berdasarkan kesimpulan di atas, penulis memberikan beberapa saran yang dapat berguna bagi beberapa pihak. Saran-saran tersebut adalah sebagai berikut :

1. Bagi perusahaan, yang terdaftar di BEI diharapkan dapat menjaga stabilitas dan peningkatan return saham dan volume perdagangan saham dengan adanya tax amnesty tahun 2016. Perusahaan jangan terlalu memfokuskan pada kebijakan tax amnesty, tetapi diharapkan lebih memfokuskan pada bagaimana cara meningkatkan kinerja perusahaan bisa lebih meningkat setelah adanya kebijakan tax amnesty, sehingga para investor bisa mempercayai perusahaan akan memberikan prospek yang bagus di masa yang akan datang.

2. Bagi instansi pemerintah, hendaknya memberikan keistimewaan terhadap perusahanperusahaan yang telah tertib dalam menjalankan kewajibankewajibanya dalam perpajakan.

3. Bagi investor, dapat menjadi pertimbangan dalam melakukan investasi didalam pasar modal.

4. Bagi penelitian selanjutnya, hendaknya memperhatikan hasil penelitian ini untuk dikembangkan lebih lanjut melalui penelitian yang lain dengan menggunakan fokus penelitian, variabel penelitian dan alat ukur yang lain, serta periode pengamatan yang lebih panjang dan luas sehingga didapatkan hasil penelitian lebih baik lagi.

\section{DAFTAR PUSTAKA}

Anggraeni, M.D. 2011. Pengaruh Pemanfaatan Fasilitas Perpajakan Sunset Policy Terhadap Tingkat Kepatuhan Wajib Pajak. Semarang: Fakultas Ekonomi Jurusan Akuntansi Universitas Diponegoro.

Anggraeni, R.S. 2014. Pengaruh Model Pembelajaran Kooperatif Tipe Picture and Picture Terhadap Hasil Belajar IPS Siswa Kelas IV SDN 01 Blembem Kecamatan Jambon Kabupaten Ponorogo Tahun Ajaran 2013/2014. Madiun: Program Study Pendidikan Guru Sekolah Dasar.

Anoraga, P. \& Ninik, W. (1992). Pasar Modal: Keberadaan dan Manfaatnya bagi Pembangunan. Jakarta; PT Rineka Cipta.

Asmorojati, W., Nur Diana \& Afifudin. 2016. Reaksi Investor Terhadap Pengumuman 
Kebijakan Tax Amnesty Pada Tanggal 1 Juli 2016. e-jurnal Ilmiah Riset Akuntansi. (http://riset.unisma.ac.id), diunduh tanggal 1 juli 2016.

Budidarmodjo \& Asc. 2016. Dilema Tax Amnesty. Business Develoment, Triwulan ke-LIV.

Budiman, A. (2017). Transparansi Usai Amnesty: Kemudahan Investasi Dana repatriasi. Majalah Pajak. hlm. 10-37.

Budiman, F \& Supatmi. 2009. Pengaruh Pengumuman Indonesia Sustainability Reporting Award (ISRA) Terhadap Abnormal Return dan Volume Perdagangan Saham (Studi Kasus Pada Perusahaan Pemenang ISRA Periode 20052008). Jurnal SNA 12 Palembang Universitas Sriwijaya. (www.multiparadigma.lecture.ub. ac.id)

Ekawati, R.K. 2011. Analisis Perbedaan Harga Saham Sebelum Dan Sesudah Pengumuman Annual Report Awards (ARA) Di Bursa Efek Jakarta. Jurnal Ilmiah STIE MDP. Vol.11 No.1: 33-41.

Fahmi, I. (2015). Pengantar Teori Portofolio dan Analisis Investasi Teori dan Soal Jawab. Jakarta Selatan; Alfabeta, Cv.

Ghozali, I. (2013). Aplikasi Analisis Multivariate dengan Program IBM SPSS 21; (Edisi ke 7). Semarang; Badan Penerbit Universitas Diponegoro.

http://ekonomi.kompas.com/read/201 6/09/07/194800126/apindo.target .uang.tebusan.tax.amnesty.pemeri ntah.ketinggian

http://ekonomi.kompas.com/read/201 6/10/01/193821326/berkat.tax.am nesty.pasar.modal.indonesia.kala hkan.singapura
http://id.termwiki.com/ID/trading_vol ume.

http://www.kompasiana.com/renindah /apa-sih-taxamnesty_553dd97f6ea8341727f3 $9 \mathrm{~b} 22$

https://m.tempo.co/read/news/2016/0 9/06/088801975/bei-tax-amnestyberi-angin-segar-ke-lantai-bursa https://www.cnnindonesia.com/ekono $\mathrm{mi} / 20170320141511-92-$ 201435/dana-repatriasi-terendusmulai-mengalir-ke-pasar-modal/

https://www.cnnindonesia.com/ekono $\mathrm{mi} / 20170323163746-92-$ 202302/ihsg-menanjak-tembusrekor-di-level-5563/

Husnan, S. (2005). Dasar-dasar Teori Portofolio dan Analisis Sekuritas; (Edisi ke 4). Yogyakarta; UPPSTIM YKPN.

Jogiyanto. (2013). Teori Portofolio dan Analisis Investasi; (Edisi ke 8). Yogyakarta; BPFE.

Kemala, K.C \& I Gusti Ketut Agung Ulupui. 2015. Reaksi Pasar Terhadap Publikasi Annual Report Award. E-Jurnal Akuntansi Universitas Udayana. ISSN 2302-8556 Vol.11 No.1 (2015): 171-185.

Keputusan Menteri Keuangan Republik Indonesia Nomor 600/KMK.03/2016.Tentang

Penetapan Bank Persepsi Yang Bertindak Sebagai Penerima Uang Tebusan Dalam Rangka Pelaksanaan Pengampunan Pajak. 2016. Jakarta:

Keputusan Presiden Republik Indonesia Nomor 53 Tahun 1990.Tentang Pasar Modal. 1990. Jakarta:

Peraturan Menteri Keuangan Republik Indonesia No. 118/PMK.03/2016.Tentang Pelaksanaan Undang-Undang Nomor 11 Tahun 2016 Tentang 
Pengampunan Pajak. 2016. Jakarta:

Rahayu, D.(2016). Analisis Reaksi Pasar Modal Terhadap Kebijakan Amnesty Pajak. Yogyakarta: Program Studi Hukum Islam Konsentrasi Keuangan \& Perbankan Syariah. (http://digilib.uinsuka.ac.id/23097/2/1320310017 BAB-I IV-atau-V DAFTARPUSTAKA.pdf), diunduh tanggal 24 november 2016.

Rusdin. (2008). Pasar Modal: Teori Masalah dan Kebijakan dalam Praktik. (Edisi ke 2). Bandung; Alfabeta, Cv.

Samsul, M., Adi, M. (Ed). (2015). Pasar Modal dan Manajemen Portofolio; (Edisi ke 2). Surabaya; Erlangga.

Sanjiwani, P.D.A \& Ketut Jati. 2017. Reaksi Pasar Modal Terhadap Kebijakan Tax Amnesty pada saat Pengumuman dan Akhir Periode I. E-Jurnal Akuntansi Universitas Udayana. ISSN 2302-8556 Vol.19 No.1: 799-826.

Santi, G.T. 2012. Pengaruh Pengungkapan Corporate Social Responsibility Terhadap Return Saham: Studi pada Perusahaan Peraih Penghargaan ISRA di BEI Tahun 2010-2012. Dian Nuswantoro.

(http://eprints.dinus.ac.id/8869/1/ jurnal 13853.pdf), diunduh pada 2014.

Siska, A.J. 2012. Perbedaan abnormal Return Perusahaan Sebelum Pada Saat dan Sesudah Pengumuman Annual Report Award. Jurnal Ekonomi STIE Haji Agus Salim Bukittinggi. Vol.XII No.2: 70-81.

Suardi, D., Adi Yuniarta \& Kadek Sinarwati. 2015. Pengaruh Pengumuman Indonesia Sustainability Reporting Award
(ISRA) Terhadap Abnormal Return dan Volume Perdagangan Saham. E-Journal S1 Ak Universitas Pendidikan Ganesha. Vol.3 No.1.

Sugiyono. (2015). Metode Penelitian Kuantitatif Kualitatif dan $R \& D$. Bandung; Alfabeta, Cv.

Taswan. (2010). Manajemen Perbankan: Konsep Teknik dan Aplikasi. (Edisi ke 2). Yogyakarta; UPPSTIM YKPN.

Undang-Undang Republik Indonesia Nomor 10 Tahun 1998.Tentang Perubahan Atas Undang-Undang Nomor 7 Tahun 1992 Tentang Perbankan. 1998. Jakarta:

Undang-Undang Republik Indonesia Nomor 11 Tahun 2016. Tentang Pengampunan Pajak. 2016. Jakarta:

Undang-Undang Republik Indonesia Nomor 8 Tahun 1995. Tentang

Pasar Modal.1995. Jakarta:

Wulandari, A.D., Arie Wahyuni \& Edy Sujana. 2017. Reaksi Investor Dalam Pasar Modal Terhadap Undang-undang Tax Amnesty. E-journal S1 Ak Universitas Pendidikan Ganesha. Vol.7 No.1.

www.pajak.go.id/amnestypajak www.yahoofinance.com www.bei.com. www.pajak.go.id/content/amnestipajak. 